\title{
Microencapsulation of Essential Oils by Spray-Drying and Influencing Factors
}

\author{
Thi Thu Trang Nguyen, ${ }^{1}$ Thi Van Anh Le, ${ }^{1}$ Nhu Ngoc Dang, ${ }^{1}$ Dan Chi Nguyen, \\ Phu Thuong Nhan Nguyen, ${ }^{3,4}$ Thanh Truc Tran,, ${ }^{5}$ Quang Vinh Nguyen, ${ }^{6}$ \\ Long Giang Bach, ${ }^{3,4}$ and Dung Thuy Nguyen Pham $\mathbb{D}^{3,4}$ \\ ${ }^{1}$ Department of Life Science, University of Science and Technology of Hanoi, Vietnam Academy of Science and Technology, \\ Ha Noi, Vietnam \\ ${ }^{2}$ Department of Advanced Materials Science and Nanotechnology, University of Science and Technology of Hanoi, \\ Vietnam Academy of Science and Technology, Ha Noi, Vietnam \\ ${ }^{3}$ NTT Hi-Tech Institute, Nguyen Tat Thanh University, Ho Chi Minh, Vietnam \\ ${ }^{4}$ Center of Excellence for Biochemistry and Natural Products, Nguyen Tat Thanh University, Ho Chi Minh, Vietnam \\ ${ }^{5}$ College of Agriculture, Can Tho University, Can Tho, Vietnam \\ ${ }^{6}$ Institute of Biotechnology and Environment, Tay Nguyen University, Buon Ma Thuot, Dak Lak, Vietnam
}

Correspondence should be addressed to Dung Thuy Nguyen Pham; pntdung@ntt.edu.vn

Received 7 January 2021; Accepted 10 June 2021; Published 24 June 2021

Academic Editor: Francisca Hernández

Copyright (C) 2021 Thi Thu Trang Nguyen et al. This is an open access article distributed under the Creative Commons Attribution License, which permits unrestricted use, distribution, and reproduction in any medium, provided the original work is properly cited.

\begin{abstract}
Essential oils (EOs) are known as any aromatic oily organic substances which are naturally synthesized in plants. Exhibiting a broad range of biological activities, EOs have played a key role in numerous industries for ages, including pharmaceutical, textile, and food. However, the volatility and high sensitivity to environmental influences pose challenges to the application of EOs on industrial scale. Microencapsulation via the spray-drying method is one of the promising techniques to overcome these challenges, thanks to the presence of wall materials that properly protect the core EOs from oxidation and evaporation. By optimization of key factors related to the infeed emulsion properties and spray-drying process, the encapsulation efficiency and retention of encapsulated EOs could be significantly improved, thus allowing a wide range of EO applications. This review attempts to discuss on different determining factors of the spray-drying process to develop an effective encapsulation formula for EOs. Furthermore, recent applications of encapsulated EOs in the fields of foods, pharmaceuticals, and textile industries are also thoroughly addressed.
\end{abstract}

\section{Introduction}

Essential volatile oils, which are commonly known as essential oils (EOs), are one of the secondary compounds naturally synthesized in various organs of aromatic plants, including fruits, leaves, flowers, bark, stalks, and roots [1,2]. Among over 300 different compounds identified in EOs, terpenoids (e.g., isoprenoids, monoterpenoids, diterpenoids, and sesquiterpenoids) are the major constituents, followed by oxygenated derivatives (e.g., alcohols, esters, aldehydes, phenols, and ketones) as well as phenylpropanoids (e.g., eugenol and cinnamaldehyde) $[1,3,4]$. Despite accounting for less than $5 \%$ of the dry basis of raw materials, EOs are essentially involved in (1) protection against herbivores and pathogen attack, (2) signaling regulation, and (3) responses to environmental stimulation. It is believed that most aromatic EOs were firstly extracted by ancient Egyptians dated back to 4500 B.C. [5]. Down the centuries, the demand for EOs has extended across the Middle East, North Africa, and Europe [6]. A tremendous amount of EOs was utilized by the ancient civilizations in Egypt, China, and India for traditional remedies, perfume production, and home cooking [7]. 
To date, the international market of EOs has reached over $\$ 17$ billion (2019), mainly distributed in food (as natural flavors, preservatives, and edible packages), pharmaceutical (functional properties), and home (as fragrance and cleaning products) segments $[8,9]$. These industries have recognized EOs as a promising alternative for synthetic chemicals, providing valuable health benefits to global consumers as well as minimizing environmental impacts.

The health-promoting benefits of EOs are given by their biological activities, which have been intensively exploited over the past few decades. Specifically, antioxidant, antimicrobial, anti-inflammation, anticancer, insecticidal [9], antipigmentation [10] and antiviral [11] properties have been recognized as highlighted properties of EOs. Firstly, the antioxidant activity of EOs is derived from their content of phenolic compounds (e.g., $\beta$-pinene, sabinene, $\gamma$-terpinene, limonene, and myrcene), targeting to free-radical scavenging and lipid peroxidation which could either prevent or cure various cell damage and diseases [12-15]. These phenolic compounds also take the main responsibility in the antimicrobial activity of EOs against a wide array of Gramnegative and Gram-positive bacteria such as E. coli [10], P. aeruginosa [14], Streptococcus spp. [16], and Lactobacillus spp. as well as many yeast and mould [17]. Due to natural lipophilicity, EOs molecules were able to penetrate through the lipids of the bacterial cytoplasmic membrane, disrupting the membrane structure and causing the loss of cell constituents [12]. EOs have also been employed in clinical treatment to treat inflammatory diseases [18]. The biologically active compounds of EOs contribute to restricting the histamine formation or diminishing the production of inflammation mediators [1]. Recently, these biological activities of EOs have even been taken to the next level by combination therapy and nanotechnology development $[19,20]$. Combinations of EOs with other EOs or with synthetic chemical agents (e.g., commercial antibiotics and antimicrobial peptide) have exerted synergistic effects towards multiple targets at a lowered dose of the individual compounds and less administration times, thus minimizing possible adverse effects as well as resistance development [21-24]. Meanwhile, the use of numerous nanomaterials as a delivery system for EOs has been shown to significantly improve EOs stability and controlled release and bioavailability while extending their efficacy and shelf-life over a prolonged period of time, thereby successfully counteracting antibiotic-resistant microbial biofilm formation and their associated chronic diseases in human, animals, and plants [25-27].

As the yield and quality of EOs are highly prone to environmental conditions, an effective extraction method is in high demand [28-30]. For this reason, an encapsulation method has been proposed to enhance the EOs stability and controlled release [31]. The process involves emulsifying core materials (e.g., EOs) with coating materials (e.g., carbohydrates or proteins) and then cooling or drying the resulted emulsion [32]. Encapsulation provides a firm protection against moisture, oxygen, light, and undesirable interactions with insects, thus minimizing their effects on the EOs shelf-life and activities [33-36]. The final products of the microencapsulation process are microcapsules with various sizes ranged from a few micrometers to a few millimeters, in the form of particles, capsules, droplets, or complexes [37].

Currently, encapsulation is performed via emulsification, coacervation, spray-drying, complexation, and nanoprecipitation methods $[38,39]$. Selection for an appropriate encapsulation method is entirely dependent on the wall material. An emulsion-based encapsulating method, which is commonly used to pack poorly water-soluble ingredients, results in discrete droplets or capsules after removing the organic solvent [40]. The coacervation technique is applied to encapsulate hydrophobic molecules, based on the electrostatic interaction between colloids that gives rise to spontaneous liquid-liquid phase separation [41]. The nanoprecipitation method, which is commonly known as solvent displacement, is relatively similar to the emulsification method. The nanoprecipitation results in the formation of nanoparticles suspension in water after solvent evaporation. Complexation is the process of adding EOs to an aqueous solution and then applying certain heat to obtain desired complexes. All four mentioned techniques present disadvantages with regards to high cost, high solvent consumption, and highly complex industrial scale [42].

Therefore, due to cost-effective operation, high retention of core materials, and effortlessly convenient equipment, spray-drying is commonly used in food as well as flavoring industries $[35,36]$. This technique physically converts EOs from a hydrophobic liquid into a more convenient lowmoist powder form, which contributes to promote the alternative use of EOs [43, 44].

The present review aims to discuss about the spraydrying process applied in EO encapsulation, focusing on (1) the factors which influence the spray-drying encapsulation efficiency as well as (2) encapsulated EOs uses in food, pharmaceutical, and textile industries.

\section{Encapsulation of EOs via the Spray- Drying Process}

2.1. Material Preparation and Process Mechanism. Spray-drying is a known a common encapsulation technique and has been well developed in pharmaceutical, chemical, food, and flavor industries [45]. Since its discovery in 1937 by A. Boake Roberts, the technique of spray-drying has played a significant role in producing various powdered flavors and encapsulating aromatic EOs [46, 47], vitamins [48], minerals [49], colorants [50], fat [51], aroma compounds [34], oleoresins [52], and enzymes [53-56]. In general, spray-drying is a flexible and low-cost method for protecting core biomaterials using spray-drying readily available equipments [44].

Materials for spray-drying are prepared by firstly dissolving the wall or coating material made from maltodextrin, modified starch, gum, or their combination and then allowing them to completely saturate in a refrigerator overnight [43]. The addition of emulsifiers may depend on emulsifying properties of the wall materials. The wall matrix: core material ratio is varied according to different 


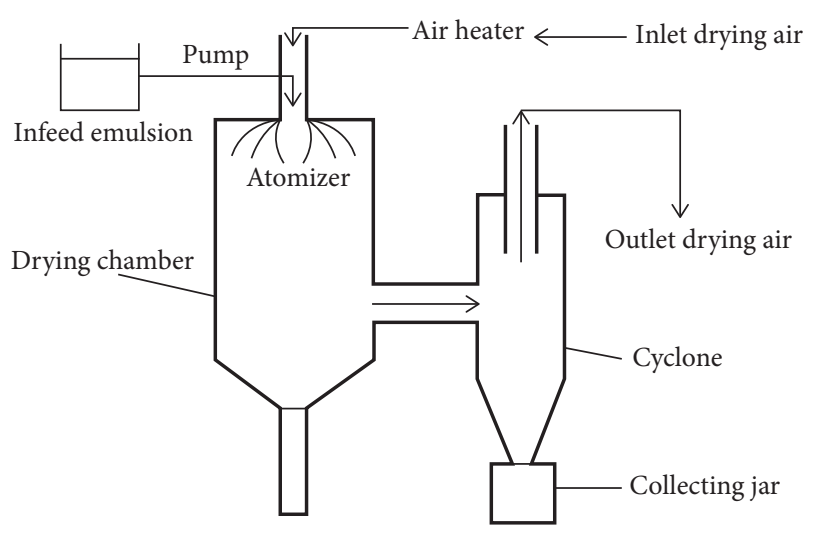

FIGURE 1: Schematic diagram of the spray dryer.

experimental conditions. The prepared oil-in-water emulsion is then speedily homogenized to produce emulsions with smaller oil globules, thus reducing the attractive forces between the globules and stabilizing infeed emulsions [54]. The mixing time at high speed is maintained. The emulsion once formed when contacted with heated air under high pressure would form a mist spread in the drying chamber (Figure 1). Three basic types of atomizers which have been broadly utilized are the high pressure nozzles, the double piston, and the spinning wheel [46]. The atomizers are responsible for producing uniform-sized, homogeneous, and smooth spray-dried particles. Next, inside the drying chamber, the hot air steam encounters the atomized droplets and dehydrates the solvent, producing dried particles which are small droplets of the core ingredient covered in a wall matrix [43]. Finally, the dried particles travel through the cyclone to the collecting jar where they are finally collected.

As a result, the spray-drying process produces highly fine discrete particles with a variety of sizes depending on the type of wall matrix material. Each particle contains a complex matrix in which EO globules are freely dispersed. As previously mentioned, the low-cost processing, available industrial-scale production, diverse encapsulating matrices, high volatile compounds retention, readily available equipment, and good quality of spray-dried particles are some significant advantages of microencapsulation by spraydrying $[36,43]$. Apart from these advantages, the main limitation is that the obtained microcapsules are partially present in an agglomerated form, which is due to fiber formation between polymeric chains [36]. Hence, this phenomenon requires the wall materials to be carefully selected in the case of liquid application $[42,43]$. Overall, spray-drying encapsulation is a low-cost and energy-efficient technology that can be applied to various food ingredients, enabling encapsulation of thermolabile compounds with low degradation risk, high encapsulation efficiency, and prolonged shelf-life.

2.2. Factors Which Affect the Efficiency of Spray-Drying Encapsulation of EOs. Successful EO encapsulation is expected to bring about high efficiency, minimum amount of unencapsulated material, and maximum retention of encapsulated powder. For this reason, a significant number of research studies have been conducted over the past few years to optimize the retention of volatile compound content in encapsulated EOs [33, 37, 51]. According to King and Hecht $[57,58]$, the volatile compounds can be lost through (1) flowing of atomized emulsion during atomization; (2) water diffusion of an unstable selective membrane, and (3) water interference towards morphological development. It is at the third stage that a greater amount of volatile compounds is lost, as compared to the others.

For a highly efficient spray-drying process, at least four criteria should be taken into consideration: (a) the type and concentration of wall materials; (b) the concentration of core materials and their composition retention; (c) the characteristics of infeed emulsion; and (d) the spray-drying conditions (Figure 2).

2.2.1. The Attributes of Wall Materials. Currently, wall materials derived from numerous natural and synthetic polymers have been employed as encapsulating agents of volatile compounds and oils. Selecting an appropriate material is an important step in infeed emulsion specification prior to spray-drying, as well as chemical interactions and volatile compounds retention throughout the process [42]. The choice of wall material is based on a number of factors regarding to the physicochemical properties of the core (e.g., solubility and porosity), the wall (e.g., molecular weight, viscosity, mechanic properties, film-forming, and emulsifying properties), compatibility, control mechanism, and economic factors [46]. Therefore, the favorable wall materials are carbohydrates such as modified and hydrolyzed starches, cellulose derivatives, gums, and cyclodextrins [32]. Among the available ingredients, maltodextrin, gum Arabic, and their combination have been commonly used due to excellent emulsifying capacities and volatile compounds retention $[33,34,37]$ (see Table 1 ).

Maltodextrin (MD) $\left[\left(\mathrm{C}_{6} \mathrm{H}_{12} \mathrm{O}_{5}\right) \cdot \mathrm{nH}_{2} \mathrm{O}\right]$ is a nonsweet polysaccharide which is made of multiple $\mathrm{D}$-glucose units linked by $\alpha$-1,4-glycosidic bonds. It normally presents as a white hygroscopic spray-dried powder or concentrated solution resulted from partial hydrolysis of corn starch with acids and/or enzymes [38]. MD is rapidly digested and absorbed as glucose and has been used as a food additive for a long time. The hydrolysis level of starch which is termed dextrose equivalent (DE) is directly associated with the degree of core material protection against oxygen penetration [39]. Using MD as the wall material is considered as inexpensive (one-third of the cost of modified starch), almost flavorless, less viscous, less hygroscopic, highly soluble in cold water, and excellently protectable for EOs, milk fat, soy oil, and fish oil [63]. MD is commonly combined with Arabic gum, modified starches, or proteins in a fixed ratio to improve the emulsifying stabilization. Thuong Nhan et al. [34] used MD and MD-gum mixture to carry out microencapsulation for lemongrass EO by spray-drying. The tested concentrations of wall material ranged from 15 to $30 \%$, and the mixture ratio was $4: 1$. Tween 80 acted as an emulsifier to improve the stabilization of infeed emulsion. 


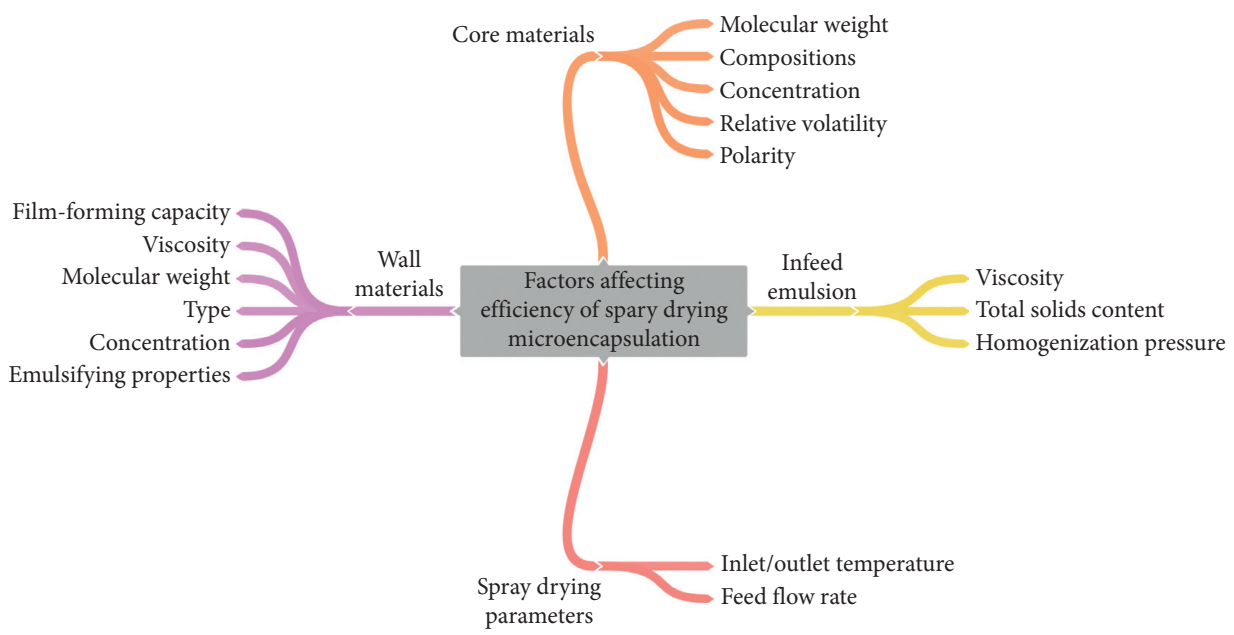

FIGURE 2: Factors affecting the encapsulation efficiency of spray-drying encapsulation.

TABLE 1: Encapsulation of EOs in different materials by spray-drying.

\begin{tabular}{|c|c|c|c|c|}
\hline Wall materials & $\begin{array}{c}\text { Core } \\
\text { materials }\end{array}$ & Concentration & Results & Reference \\
\hline $\begin{array}{l}\text { Individual MD and MD-GA } \\
\text { combination }(4: 1)\end{array}$ & $\begin{array}{l}\text { Lemongrass } \\
\text { EO }\end{array}$ & $15-30 \%$ & $\begin{array}{c}\text { MD in individual form at } 30 \% \text { of } \\
\text { concentration effectively encapsulated } \\
\text { lemongrass EO at high encapsulation } \\
\text { efficiency }(84.75 \%) \text { and oil retention } \\
(89.31 \%)\end{array}$ & $\begin{array}{l}\text { Thuong Nhan } \\
\text { et al. [34] }\end{array}$ \\
\hline MD and GA combination & Lavender EO & $\begin{array}{l}\text { MD (25-58.33 of total } \\
\text { solid) and GA ( } 25-50 \% \\
\text { of total solid) }\end{array}$ & $\begin{array}{l}\text { The highest encapsulation efficiency } \\
\text { was obtained and minimum oil } \\
\text { loading }\end{array}$ & Burhan et al. [33] \\
\hline $\begin{array}{l}\text { HPMC-MD-CSD mixtures }(1: 1: 0 \\
\text { and } 2: 1: 1)\end{array}$ & Oregano EO & - & $\begin{array}{l}\text { The relation } 2: 1(\mathrm{WM}: \mathrm{C} \text { ) without } \\
\text { CSD enhanced the antioxidant } \\
\text { activity and retention of volatile } \\
\text { compounds after } 90 \text { days of storage }\end{array}$ & Asensio et al. [59] \\
\hline $\begin{array}{l}\text { Mesquite gum (MG), nopal mucilage } \\
(\mathrm{NM}) \text {, and MG-NM mixtures }(1: 3 \text {, } \\
1: 1 \text {, and } 3: 1)\end{array}$ & Lemon EO & $\begin{array}{l}30 \% \text { of total solid } \\
\text { content }(w / w)\end{array}$ & $\begin{array}{l}\text { MG-NM combination exhibited a } \\
\text { synergic effect in giving rise to } \\
\text { desirable retention and shelf-life } \\
\text { extension for lemon EO }\end{array}$ & $\begin{array}{l}\text { Cortés-Camargo } \\
\text { et al. [60] }\end{array}$ \\
\hline MD-IP, MD-OSA, and MD-OSA-IP & Avocado EO & $\begin{array}{c}\text { OSA equals to } 3 \% \mathrm{MD} \\
\text { base and IP : MD ratio } \\
\text { equals to } 1: 9\end{array}$ & $\begin{array}{c}\text { The OSA modification of MD reduced } \\
\text { by about } 80 \% \text { the oxidation of the EO } \\
\text { as compared to its nonmodified } \\
\text { counterpart }\end{array}$ & $\begin{array}{l}\text { Sotelo-Bautista } \\
\text { et al. [61] }\end{array}$ \\
\hline $\begin{array}{l}\text { GA, MD, MS, GA-MD mixtures }(3: \\
1,1: 1,1: 3) \text {, GA-MS mixtures }(3: 1 \text {, } \\
1: 1,1: 3) \text {, and GA-MD-MS mixtures } \\
(1: 1: 1,4: 1: 1,1: 4: 1 \text {, and } 1: 1: 4)\end{array}$ & Lemon EO & $30 \%$ & $\begin{array}{l}\text { GA produced the highest } \\
\text { encapsulation efficiency, followed by } \\
\text { MS and MD. }\end{array}$ & $\begin{array}{l}\text { Kausadikar, } \\
\text { Gadhave, and } \\
\text { Waghmare [62] }\end{array}$ \\
\hline
\end{tabular}

EO- essential oil, MD- maltodextrin, GA- gum Arabic, HPMC- hydroxypropyl methyl cellulose, CSD- colloidal silicon dioxide, IP- isolated protein, OSAoctenylsuccinic anhydride, MS- modified starch

Results have shown that lemongrass EOs (1.5\%) had been encapsulated by MD (30\%) at significant efficiency $(84.75 \%)$ without interfering most of the Eos' chemical composition and product quality. MD has also been blended with whey protein isolate (MD-PI), octenylsuccinic anhydride (MDOSA), and their combination (MD-OSA-PI) for avocado EO encapsulation. The MD-OSA blend produced homogenoussized microcapsules which maintained EO stability for three weeks after the experiment, yet the encapsulation efficiency was the lowest, due to the sensitiveness of OSA to light and oxidation $[61,64]$. Another work conducted by Asensio et al.
[59] had successfully microencapsulated oregano EO by spray-drying using combinations of MD with hydroxypropyl methyl cellulose (HPMC) and colloidal silicon dioxide at $1: 1: 0$ and $2: 1: 1$ ratios as wall materials. Interestingly, the oregano $\mathrm{EO}$ microcapsules without CSD exhibited high antioxidant activity and lowered release of volatile compounds after 90 days of storage.

Gum Arabic (GA) obtained from the Acacia stems and branches mainly consists of complex polysaccharides (approximately $500 \mathrm{kDa}$ ), along with their potassium, calcium, and magnesium salts. Up to the present, GA is commercially 
available in various forms, ranging from white to yellowishwhite flakes, granules, powder, roller-dried, or spray-dried material [39]. GA is commonly employed as an emulsifier, stabilizer, and thickener in the production of confectionery and beverage industries due to high solubility, high oxidative stability, and excellent emulsification in a wide range of $\mathrm{pH}$ $[65,66]$. Regarding EO encapsulation by spray-drying, GA is a common wall material due to high retention of many volatile compounds during the process. However, GA application faces difficulties in high cost, limited availability, and contamination. Therefore, researchers have made an attempt to either combine GA with different materials or to exploit for other alternatives [32].

Rajabi et al. [67] described the use of three types of wall materials (maltodextrin, gum Arabic, and gelatin) alone or in combinations for the microencapsulation of saffron extract by the spray-drying technique. As seen from the concerned blends, the stability of saffron bioactive compounds increased as the quantity of gelatin decreased in its blend with maltodextrin and gum Arabic up to $1 \%(\mathrm{w} / \mathrm{w})$. The microencapsulation process was optimized at $40 \%$ total solids, consisting of maltodextrin, gum Arabic, and gelatin in the $\mathrm{w} / \mathrm{w}$ ratio of $0.94: 0.05: 0.01$.

Guergoletto et al. [68] invested a study on, in vitro, the antioxidant capacity and prooxidant effects of juçara pulp fermented with two bacterial strains before and after spraydrying with maltodextrin, gum Arabic, or gelatin and storage at $25^{\circ} \mathrm{C}$ for 90 days. The reduction in total phenolic content and antioxidant capacity was recorded when the samples were dried with maltodextrin (24\% decrease of total phenolic content and 19\% of DPPH scavenging), followed by gum Arabic (decrease of 50.7 and 69\%) and gelatin (decrease of 61 and $78 \%)$.

Flores-Belmont et al. [69] evaluated the survival of Lactobacillus acidophilus in model gastrointestinal conditions through microencapsulation by simple or double spray-drying using chitosan-inulin or chitosan-maltodextrin $(1: 15$ or $1: 25)$ solutions. A microbial reduction of $7 \mathrm{log}$ cycles was obtained for the simple microencapsulated probiotic and only 3 log reductions for the double microencapsulated probiotic. The double microencapsulated probiotic, thus, demonstrated greater resistance to simulated gastrointestinal conditions.

Kausadikar, Gadhave, and Waghmare [62] have used native $\mathrm{MD}$, native $\mathrm{GA}$, native modified starch (MS), GA mixed with MD (the ratios of $3: 1,1: 1,1: 3$ ), and GA mixed with MS (the ratios of $3: 1,1: 1 ; 1: 3$ ) as the wall materials for the encapsulation of lemon oil by spray-drying. The result showed that the encapsulation efficiency ranged from $50.52 \%$ to $83.60 \%$ with the highest value obtained from $1: 1$ GA-MS and the lowest value obtained from native MD. The encapsulation efficiency of GA was the highest, followed by MS and MD. Moreover, GA was recommended to blend with MD and MS to reduce production costs.

Wall materials made of GA-MD combination were used to encapsulate the lavender EO liquid into a solid powdered form using the spray-drying method. The optimal ratio of GA, solid concentration, and oil loading was found as $25 \mathrm{w} /$ $\mathrm{w} \%, 30 \mathrm{w} / \mathrm{w} \%$, and $16.67 \mathrm{w} / \mathrm{w} \%$, respectively, producing lavender oil microencapsulates at high encapsulation efficiency $(77.89 \%)$ and remaining stable for up to 1 month of storage. However, once the content of either solid concentration or GA outweighed each other, such protective effect would suffer from high viscosity, delayed particle formation, and reduced solubility, which lead to low powder yield as well as EO volatilization and loss during the drying process. In general, these studies have proposed that a suitable wall material plays a key role in protecting the loaded active compounds and maintaining the microencapsulates' stability for use and storage in a long run. Beside the favorable use of MD and GA, the disadvantages of each individual compound should be improved via new formulation and strategies to enable clinical and industrial applications. In addition, the search for alternative materials and combinations, as well as optimization work, should be further extended to construct a specifically effective spraydrying encapsulation process for each EO.

2.2.2. The Properties of Core Material. Over the years, EOs from lemongrass [34], thyme [33], lavender [37], oregano [59], avocado [61], lemon [62], and cinnamon [70] have been successfully encapsulated by spray-drying. These studies reported in general that the spray-drying encapsulation acted as a protective barrier for the EO during processing, storage, and transport, thereby actively preventing the loss, volatilization, and degradation of EO as well as their chemical modification [71].

Despite the fact that spray-drying microencapsulation would mainly attempt to restrain the volatile compounds loss, the retention is also affected by the molecular weight, polarity, and relative volatility of the volatile compounds [32]. Firstly, the molecular weight of volatile compounds is the primary factor which determines their diffusion rate. A high molecular weight allows the compounds to have more interaction time with the atomized droplet surface during the drying process, thus increasing the volatile retention. The second factor that determines volatile retention is the relative volatility [72]. For instance, the retention of octanol, octenol, octanon, and octanal was correlated with their relative volatility when they were encapsulated with maltodextrin before spray-drying [72]. As a result, the higher the relative volatility was, the lower the retention was. The third factor is the polarity of volatile compounds. Studies have shown that the volatile compounds would become more polar when dissolving in water for a long time. Water fractions when passing through the selective membrane even at the late stage of the drying process enhance the volatile polarity, thus promoting volatile compounds loss [73]. Next, volatile compounds retention can also be varied according to their chemical composition. Goubet et al. [74] proved the retention of aromatic compounds increased proportionally with the functional group polarity. Besides, the retention of volatile compounds may indirectly depend on the physicochemical properties of the volatiles [75].

Particularly, the concentration of core materials or EOs significantly influences the volatiles retention as well as encapsulation efficiency. Optimally, the concentration 
should provide high core retaining content and drying yield at a lowered cost and energy consumption. For example, upon encapsulation into GA wall material via the spraydrying method, increasing concentrations of lemon EO from $10 \%$ to $20 \%$ reduced the encapsulation efficiency of approximately over $10 \%$ [62]. Similarly, Frascareli et al. [76] and Thuong Nhan et al. [34] found that the total retention of coffee and lemongrass EO was dramatically dropped when an excessive concentration of these oils was loaded into the encapsulating particle. A possible explanation could be that the high oil concentration would enhance the emulsion viscosity which limits the oil diffusion to the drying particle surface.

\subsubsection{The Characteristics of Infeed Emulsion.} Encapsulation efficiency of EO and volatile retention by using the spray-drying method are solely dependent on the infeed emulsion. In order to prepare an effective infeed emulsion, the following parameters are taken into consideration: (1) total solid content, (2) emulsion stability, viscosity, size, and method, and (3) homogenization pressure.

The total content of solids determines the EOs encapsulation efficiency during spray-drying by regulating the emulsion viscosity and modulating the droplets circulation, leading to rapid semipermeable crust formation [32]. Estimating an optimum total solid content could prevent wasting wall materials and maintain the emulsion viscosity as well as stability at an appropriate level for better retention. Homogenization pressure could also affect the emulsion properties and encapsulation efficiency of spray-drying. In a study conducted by Frascareli et al. [76], the effect of various homogenization pressure $(0-100 \mathrm{MPa})$ on the droplet size, emulsion viscosity, and the oil retention of microencapsulated basil EO was evaluated. Results have shown that increasing the pressure up to $50 \mathrm{MPa}$ could break down the emulsion droplet to smaller sizes. In contrast, as the pressure continued to rise beyond $85 \mathrm{MPa}$, Brownian motion of the droplets and performance of emulsifiers are increased [77], causing the droplets to become thermodynamically unstable and coagulate with other droplets [72]. Homogenization pressure had no significant effect on viscosity, yet positively affected the oil retention.

Jafari et al. [73] completely discussed about the influence of infeed solid concentration on the rapid formation of crust on the surface of the droplet. As infeed solids concentration as well as emulsion viscosity increased up to an optimum point, the internal circulations and oscillations inside the droplets will be reduced. At the optimum viscosity, the atomization process will be easy to perform; thus, rapid a semipermeable membrane and reasonably spherical particles will be formed. In parallel, the selective diffusion will be put into action earlier, the volatile compounds will be rapidly trapped, and the retention will be improved. However, the viscosity beyond its optimum limit will produce larger droplet sizes. During atomization, larger droplet sizes cause the larger exposures and the slow formation of discrete particles. The more thermal exposure leads to a rational decrease of the retention.
2.2.4. Temperature and Feed Flow Rate. Apart from initial emulsion, selection for an appropriate feed flow rate and the inlet and outlet drying air temperatures also contributes to maximize the encapsulation efficiency.

Numerous studies have reported the influences of drying temperature on coffee EO [76], fish EO [77], mandarin EO [78], and lemon EO [60,62]. These studies proposed that the optimal range of inlet temperature for effective spray-drying encapsulation was between $160^{\circ} \mathrm{C}$ and $220^{\circ} \mathrm{C}$, at which rapid semipermeable membrane formation and high flavor retention occurred [32].

The feed flow rate also significantly affects the physical properties of microencapsulates. Fernandes et al. [79] investigated the influence of various feed flow rates $\left(0.5-1.0 \mathrm{~L} \mathrm{~h}^{-1}\right)$ and inlet air temperatures $\left(135-195^{\circ} \mathrm{C}\right)$ on rosemary EO microencapsulation. Results showed that high temperature combined with slow rate of feed flow resulted in lowered particle moisture content, hygroscopicity, and wettability of the powders. This study suggested that the best spray-drying conditions included the wall material concentration of $24 \%$, the inlet temperature of $135^{\circ} \mathrm{C}$, and the feed flow rate of $0.7 \mathrm{~L} \mathrm{~h}^{-1}$. Another work has been carried out by Maskat et al. [80] to determine the effects of inlet air temperature $\left(150,160\right.$, and $\left.170^{\circ} \mathrm{C}\right)$ and feed rate $\left(280,350\right.$, and $\left.420 \mathrm{~mL} \mathrm{~h}^{-1}\right)$ on encapsulating roselle extract by spray-drying. These two factors significantly affected yield, color, moisture, and anthocyanin content of spray-dried roselle, whereby increasing feed flow rate would reduce the moisture content and promote anthocyanin degradation.

\section{Applications of Microencapsulated EOs}

As compared to other microencapsulation methods, spraydrying has shown several dominant advantages such as equipment availability, materials diversity, and large-scale production of microencapsulates with high retention and stability and low processing cost, hence their favorable use for numerous EOs [81]. EOs encapsulated by spray-drying is applied in foods, pharmaceuticals, textiles, and footwear products (see Table 2).

3.1. Food Sector. Food spoilage and decay caused by bacteria and fungi during postharvest, processing, and storage stages results in tremendous economic losses and consumer dissatisfaction [109-111]. As applications of food preservatives and fungicides may unexpectedly increase the toxicity level of the food, as well as trigger resistance development $[42,112]$. Consumer preferences have shifted towards natural-based alternatives (i.e., biopreservatives or "green" preservatives) which appear to be healthier and more ecofriendly and cost effective [113]. In this regards, EOs have been favorably employed.

Kringel et al. [84] carried out a work to demonstrate the strong antifungal activity of orange EO in bakery products. The EO was loaded into a zein and $\beta$-cyclodextrin combination and inhibited the growth of $A$. terreus, A. Niger, and A. fumigatus. In the presence of encapsulated orange EO, the 
TABLE 2: Microencapsulated EOs applied in various fields.

\begin{tabular}{|c|c|c|c|c|}
\hline $\begin{array}{l}\text { Fields of } \\
\text { application }\end{array}$ & Type of EO & Purpose & Result & Reference \\
\hline \multirow{8}{*}{ Food } & Thyme EO & Antimicrobial & $\begin{array}{c}\text { Thyme EO encapsulated by casein- } \\
\text { maltodextrin by the spray-drying method } \\
\text { exhibited antioxidant, as well as in vitro and } \\
\text { in situ antibacterial against } L \text {. monocytogenes, } \\
\text { E. coli, and S. typhimurium were also } \\
\text { inhibited }\end{array}$ & Radünz et al. [82] \\
\hline & Lemongrass EO & Insecticidal & $\begin{array}{l}\text { The release of citral from the encapsulated } \\
\text { lemongrass } \\
\text { EO in a slow and controlled manner has } \\
\text { exerted an } \\
\text { insecticidal effect against potato tuber moth } \\
\text { up to one week of experiment }\end{array}$ & Jovanović et al. [83] \\
\hline & Orange EO & Antifungal & $\begin{array}{l}\text { Encapsulation into zein and } \beta \text {-cyclodextrin } \\
\text { complexes has enhanced the capability of } \\
\text { orange EO in decelerating the cake spoilage } \\
\text { caused by } A \text {. terreus, } A \text {. Niger, and } \\
\text { A. fumigatus growth from } 30 \text { to } 150 \text { days }\end{array}$ & Kringel et al. [84] \\
\hline & $\begin{array}{c}\text { Lamiaceae EO and } \\
\text { oregano EO }\end{array}$ & Antifungal & $\begin{array}{l}\text { The use of niosome-based encapsulated EOs } \\
\text { has reduced the fungal growth and aflatoxin } \\
\text { accumulation in maize grains for } 75 \text { days }\end{array}$ & García-Díaz et al. [85] \\
\hline & Oregano EO & Antifungal & $\begin{array}{l}\text { Nanoencapsulated oregano EO inhibited the } \\
\text { growth of Cladosporium sp., Fusarium sp., } \\
\text { and Penicillium sp. isolated from Minas } \\
\text { Padrão cheese }\end{array}$ & Bedoya-Serna et al. [86] \\
\hline & Rosemary EO & Antibacterial & $\begin{array}{l}\text { Encapsulation of rosemary EO onto chitosan- } \\
\text { benzoic acid nanogel reduced the growth of } \\
\text { S. typhimurium which helped in extending } \\
\text { meat shelf-life }\end{array}$ & Hadian et al. [87] \\
\hline & Lemon EO & Stability & $\begin{array}{l}\text { Stability of encapsulated lemon oil was } \\
\text { maintained up to } 6 \text { months }\end{array}$ & Kausadikar et al. [62] \\
\hline & Rosemary EO & Antimicrobial & $\begin{array}{l}\text { The mucilage-coated rosemary EO } \\
\text { maintained the ascorbic acid content and } \\
\text { color, reduced peroxidase enzyme, and } \\
\text { inhibited microbial growth }\end{array}$ & Alikhani [46] \\
\hline \multirow{2}{*}{ Food Packaging } & Cinnamon EO & Antimicrobial & $\begin{array}{l}\text { The } \mathrm{Ag}^{+} / \mathrm{Zn}^{2+} \text {-permutite containing } \\
\text { cinnamon EO showed sustained release and } \\
\text { strong inhibitory activity against Aspergillus } \\
\text { Niger and Penicillium sp., thus controlling the } \\
\text { degradation of fresh Chinese bayberry }\end{array}$ & Niu et al. [88] \\
\hline & Lemongrass EO & Antimicrobial & $\begin{array}{l}\text { Lemongrass EOs was sustainably released } \\
\text { from alginate films and exhibited } \\
\text { antimicrobial activities against E. coli and } \\
\text { B. cinerea. Such activity was affected by the } \\
\text { droplet size and storage conditions }\left(4^{\circ} \mathrm{C}\right)\end{array}$ & Riquelme et al. [89] \\
\hline
\end{tabular}


TABle 2: Continued.

\begin{tabular}{|c|c|c|c|c|}
\hline $\begin{array}{l}\text { Fields of } \\
\text { application }\end{array}$ & Type of EO & Purpose & Result & Reference \\
\hline \multirow{10}{*}{ Pharmaceutical } & Thyme EO & $\begin{array}{l}\text { Antimicrobial and } \\
\text { stability }\end{array}$ & $\begin{array}{l}\text { Upon encapsulation to lipid matrix } \\
\text { microparticles, thyme EOs quality was stable } \\
\text { during feed pelleting and storage processes. } \\
\text { In addition, the oil was slowly released in a } \\
\text { controlled manner in weaned pigs }\end{array}$ & Choi et al. [90] \\
\hline & Jasmine EO & $\begin{array}{l}\text { Antioxidant and } \\
\text { anticancer }\end{array}$ & $\begin{array}{c}\text { By loading onto pectin/chitosan } \\
\text { nanoparticles, the anticancer } \\
\text { activity of jasmine EO against MCF-7 breast } \\
\text { cancer cells was } \\
\text { 13-folded improved, possibly due to } \\
\text { enhanced thermal stability }\end{array}$ & Attallah et al. [91] \\
\hline & Lime EO & $\begin{array}{c}\text { Propionibacterium acne } \\
\text { treatment }\end{array}$ & $\begin{array}{l}\text { Results from disk difusion assay have shown } \\
\text { that lime EO encapsulated into chitosan } \\
\text { nanoparticles has improved its inhibitory } \\
\text { activity against Propionibacterium acnes, as } \\
\text { compared to the nonencapsulated formula }\end{array}$ & Julianti and Rusliati [92] \\
\hline & Rosemary EO & $\begin{array}{l}\text { Antimicrobial and } \\
\text { wound healing }\end{array}$ & $\begin{array}{c}\text { Rosemary EO loaded into the lipid } \\
\text { nanocarriers (NLCs) inhibited Streptococcus } \\
\text { epidermidis, Streptococcus aureus, E. coli, } \\
\text { Listeria monocytogenes, and Pseudomonas } \\
\text { aeruginosa. It also accelerated wound healing } \\
\text { and reduced the rate of tissue bacterial } \\
\text { colonization }\end{array}$ & Khezri et al. [93] \\
\hline & Vetiver EO & $\begin{array}{l}\text { Sedative activity and } \\
\text { hypnotic activity }\end{array}$ & $\begin{array}{l}\text { Vetiver oil cross-linked polymeric } \\
\text { microcapsules were able to provide a } \\
\text { sustained release of encapsulated oil }\end{array}$ & Ali et al. [94] \\
\hline & Peppermint EO & $\begin{array}{l}\text { Antibacterial activity } \\
\text { and wound healing }\end{array}$ & $\begin{array}{l}\text { Peppermint-EO-loaded nanostructured lipid } \\
\text { carriers (NLC) showed antibacterial activity } \\
\text { against S. epidermidis, L. monocytogenes, } \\
\text { E. coli, P. aeruginosa, and S. aureus. The } \\
\text { animals administered with NLC showed } \\
\text { increasing wound contraction rate }\end{array}$ & Ghodrati et al. [95] \\
\hline & Babchi EO & $\begin{array}{l}\text { Dermatological } \\
\text { treatment }\end{array}$ & $\begin{array}{c}\text { Encapsulation of Babchi EO in microsponges } \\
\text { exhibited antimicrobial activity against } \\
\text { P. aeruginosa, S. aureus, and E. coli. }\end{array}$ & Wadhwa et al. [96] \\
\hline & Rosemary EO & Anti-inflammatory & $\begin{array}{l}\text { Nanoemulsion containing rosemary EO was } \\
\text { confirmed to inhibit the inflammatory } \\
\text { process in zebrafish }\end{array}$ & Borges et al. [97] \\
\hline & Citronella EO & Mosquito repellent & $\begin{array}{c}\text { The efficiency of applying } \beta \text {-cyclodextrin } \\
\text { containing the citronella oil system as } \\
\text { repellent against Aedes aegypti was } 84.67 \% \\
\text { after } 5 \text { minutes }\end{array}$ & Pujiastuti et al. [98] \\
\hline & Cardamom EO & Antimicrobial & $\begin{array}{c}\text { Cardamom-oil-loaded chitosan } \\
\text { nanoparticles combatted } \beta \text {-lactamase- } \\
\text { producing E. coli and MRSA }\end{array}$ & Jamil et al. [99] \\
\hline
\end{tabular}


TABle 2: Continued.

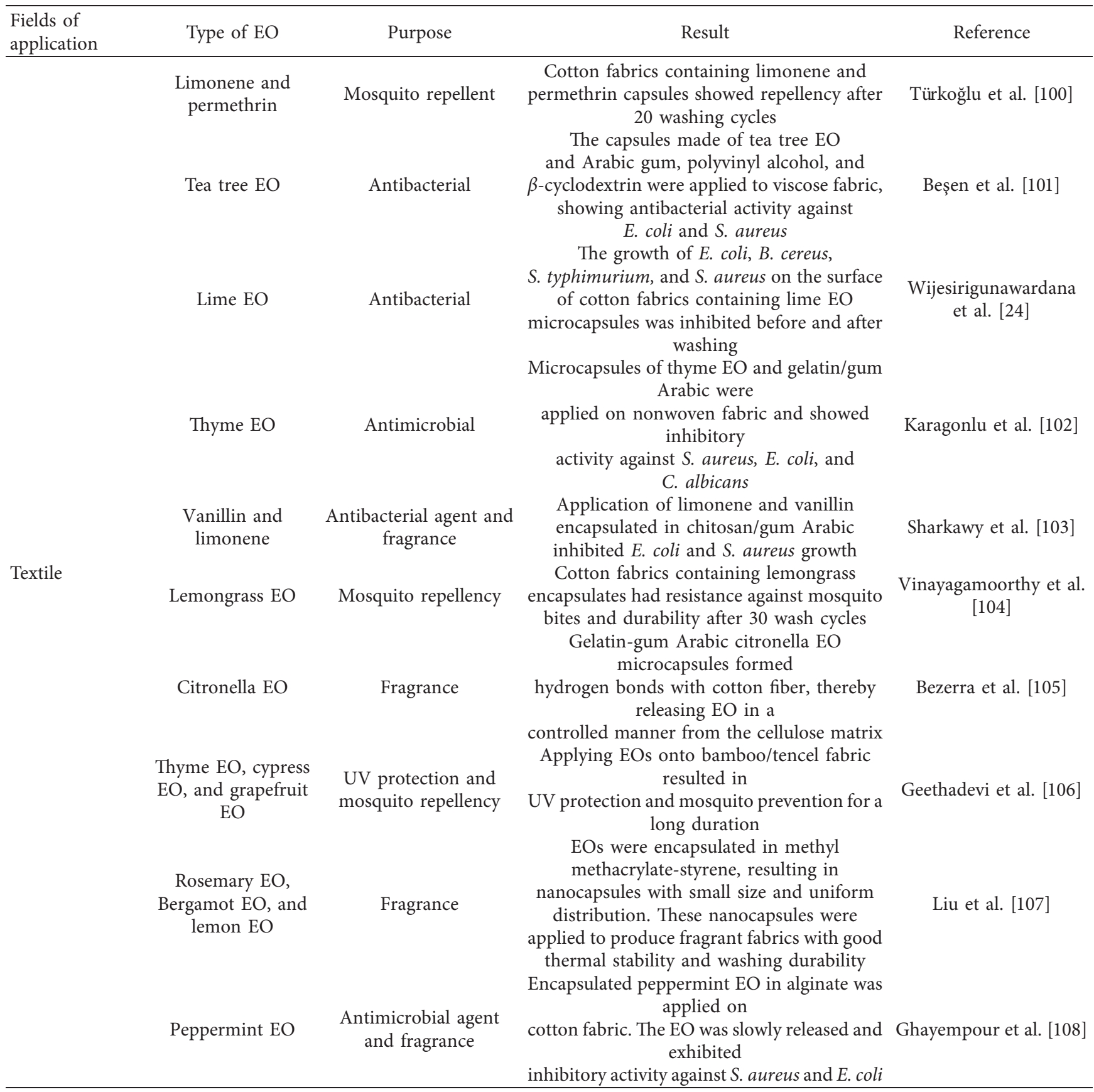

microbiological spoilage was restrained up to 5 months, indicating its potential to extend the shelf-life of bakery products. In another study conducted by Alikhani [46], rosemary EO coated by mucilage was able to maintain the ascorbic acid content and customer satisfaction, while decreasing the rate of peroxidase activity and microbial growth. The results indicated that application of mucilage encapsulated rosemary EO effectively prolonged the quality and extended the storage period of sliced mango. Overall, the strong inhibitory activity against fungi and bacteria of encapsulated EOs applied in food products has been well documented in several reports [85-87, 114-116].
In addition to antimicrobial activity, the insecticidal effect of encapsulated lemongrass EO against Phthorimaea operculella was investigated by Jovanović et al. [83]. The release of the citral compound present in the encapsulated EO has caused a lethal effect to the potato tuber moth for seven days as compared to the nonencapsulated one. Recently, the use of encapsulated EOs has emerged in food industry as a safe and high-quality packaging for food products [117]. Nanoencapsulation is reported to improve EOs' solubility, stability, and volatilization, thereby maintaining their biological activities during transport and storage. For example, according to Hadian et al. [87], the 
chitosan-benzoic acid nanogel has improved the antioxidant and antimicrobial activities, as well as stability of rosemary EOs. The nanoencapsulated rosemary EOs could be used as an effective tool to reduce Salmonella spp. and extend the shelf-life of meat.

3.2. Pharmaceutical Sector. Regarding the pharmaceutical field, EOs are firstly considered as an effective alternative for conventional antibiotics to combat multidrug-resistant pathogens, whose development is derived from indiscriminate use of antibiotics [118]. Indeed, Khezri et al. [93] have investigated the antimicrobial activity and wound-healing capacity of rosemary EO loaded into lipid nanocarriers (REO-NLCs). Results have shown that, in addition to in vitro antibacterial activity against several Gram-positive and Gram-negative bacteria, REO-NLCs also promoted wound healing in mice by reducing bacterial density, vascularization, and re-epithelialization. A similar observation was reported by Ghodrati et al. [95]. By loading onto NLCs, peppermint EO exhibited antibacterial activity and in vivo wound-healing effect. Meanwhile, according to Jamil et al. [99], cardamom EO encapsulated into chitosan nanoparticles was able to combat $\beta$-lactamase-producing multidrug-resistant E. coli.

Secondly, the applications of encapsulated EO have been branched towards mosquito-borne diseases and anti-inflammation. For instance, Pujiastuti et al. [98] have reported the mosquito-repellent action of citronella EO contained in $\beta$-cyclodextrin. The liquid microcapsules upon application onto the mice skin showed repellency percentage of $84.67 \%$ after $5 \mathrm{~min}$. Along with the mosquito-repellent activity, the encapsulated oil had a lowered volatility rate. In terms of antiinflammatory activity, Wijayadi and Rusli [119] revealed that encapsulating lime EO into chitosan nanoparticles improved the inhibitory activity of the EO against Propionibacterium acnes with minimal side effects. Wadhwa et al. [96] has formulated Babchi EO encapsulated in ethyl cellulose microsponges for dermatological treatment. The formulation effectively inhibited $P$. aeruginosa, S. aureus, and E. coli. The safety and stability of the prepared microsponges on dermal cells were also enhanced, as compared to the nonencapsulates. Furthermore, Ali et al. [94] developed a polymeric encapsulation system for vetiver EO. The presence of SA and gellan gum as wall material allowed EO release in a sustained manner and exhibited a sedative-hypnotic activity in an animal model. Notably, thyme EOs and lauric acid were loaded into alginate microparticles to maintain the oil stability during processing, showing a controlled release profile in a simulated intestinal tract environment. Encapsulation of EO has also been applied in fabrication of anticancer delivery systems. For instance, jasmine EO encapsulated into pectin/chitosan composite nanoparticles has been shown to exhibit anticancer activity approximately 13 times higher than the nonencapsulated EO and enhanced normal cell viability [91].

3.3. Textile Sector. During the past few decades, mosquitoborne diseases such as dengue fever and malaria have vastly caused severe harm to millions of people worldwide [120].
Hygiene has, therefore, become one of the major concerns among the world population. To date, the use of EOs has emerged in textile industry as a revolutionary alternative for synthetic repellents, taking advantage of their natural antimicrobial ability, nontoxicity, nonirritation, and environment friendliness [121, 122]. With the advances in microencapsulation techniques, the loss and deterioration of EO-based mosquito repellents due to oxidation and volatilization can be prevented throughout a long period of time [123-125]. According to Özyildiz et al. [126], the disposable nonwoven fabrics containing ozonated red pepper seed EO microcapsules actively reduced up to $5 \mathrm{log}$ of antibioticresistant micro-organisms in $1 \mathrm{~h}$. In another work conducted by Kim and Sharma [75], the application of microcapsules made of red thyme EOs combined with clove bud into fabrics has helped in getting rid of $94 \%$ of harmful household dust mites. Meanwhile, Türkoğlu et al. [100] have used limonene and permethrin capsules to provide mosquito-repellent activity for cotton fabrics. The treated fabrics were protected from mosquitoes, with mortality rates of $41 \%$ and $54 \%$ for limonene and permethrin, respectively. The repellent efficiency of fabrics remained after 20 washing cycles. Antimicroorganism textile has also been exploited to prevent colonization of skin pathogenic as well as odorgenerating bacteria and fungi [127]. Beşen et al. [101] attempted to produce disposable fabric (100\% viscose nonwoven) containing tea tree EO microcapsules. The fabric exhibited antibacterial activity against $S$. aureus and E. coli. Meanwhile, Wijesirigunawardana et al. [24] demonstrated that cotton fabric carrying lime EO microcapsules effectively inhibited E. coli, B. cereus, S. typhimurium, and S. aureus even after washing. Similarly, antimicrobial effects against S. aureus, E. coli, and C. albicans were observed when applying gelatin-gum Arabic thyme EO microcapsules at different concentrations onto fabrics [102].

The encapsulated EO also produced scent and UV protection. Bezerra et al. [105] carried out production of fragrant textile using encapsulated citronella EO. The cotton fiber formed a hydrogen bond with the microcapsules, aiding in controlled release of EO from the cellulose matrix. Geethadevi and Maheshwari [106] reported the UV protection of bamboo/tencel fabric containing encapsulated thyme EO, cypress EO, and grapefruit EO. These EOs formed a firm layer on the fabric surface to prevent sunray penetration. The fabric durability of UV protection was enhanced up to 30 washes.

\section{Conclusions and Future Perspectives}

For centuries, the diversity of composition and biological activities have made EOs a crucial provider of health benefits to the global population. Up to the present time, EOs have been employed in various industries as a natural and healthy alternative for synthetic chemicals. However, the stability of EOs against adverse conditions during manufacturing, storage, and transport raises a major concern about their quality degradation and concentration loss as well as nontarget delivery. Therefore, encapsulation via the spray-drying method has been widely proposed to effectively 
overcome these limitations, producing EO powder with extended longevity at a relatively low cost. Furthermore, the biological activity, controlled release, and quality of EOs can also be maintained.

Regarding the spray-drying encapsulation method, four parameters related to the process itself and emulsion properties would be taken into consideration: the attributes of wall materials, the profiles of core materials, the characteristic of infeed emulsion, the inlet/outlet temperature, and the feed flow rate of the pump. Optimization work for each of these parameters is required to continue to provide optimal conditions in order to (1) achieve maximum encapsulation efficiency and oil retention and (2) maintain controlled release and efficacy of encapsulated EOs, thereby extending their use and applications. Numerous studies have shown that food, pharmaceutical, and textile are among the segments in which EO encapsulation is most commonly applied. In the food industry, the presence of microencapsulates plays a crucial role in preventing food degradation by taking advantage of antimicrobial and insecticidal activities over a prolonged storage time. In the pharmaceutical industry, release of encapsulated EOs in a sustained manner effectively targeted multidrug-resistant bacteria, skin inflammation, and cancer cells in animal models. In the textile industry, the fabrics containing encapsulated EOs exhibited remarkable repellent activity against mosquitos and micro-organisms and UV damage after multiple washing times. This evidence has again highlighted the essential role of EO encapsulation and provided helpful insights for further exploitation in the future.

The potential application of EO microencapsulation has been investigated under various environmental conditions. Based on the current insights, it is recommended to investigate the effects of storage time and handling practices on the encapsulated EO retention. Further studies on sensorial analysis of encapsulated EOs could be conducted to improve consumer satisfaction and economic profits. In addition, evaluation of the product hygroscopicity under different humid conditions is required to support the storage time prediction as well as selection for compatible packaging materials. Finally, the exploration for new wall materials should also be in demand to extend the use of encapsulated EOs toward environmental sustainability and cost efficiency.

\section{Data Availability}

No data were used to support this study.

\section{Conflicts of Interest}

The authors declare no conflicts of interest.

\section{Authors' Contributions}

Nguyen Thi Thu Trang, Le Thi Van Anh, Dang Nhu Ngoc, Nguyen Dan Chi, Nguyen Phu Thuong Nhan, Tran Thanh Truc, Nguyen Quang Vinh, Long Giang Bach, and Pham Nguyen Thuy Dung conducted investigation; Le Thi Van Anh and Long Giang Bach supervised the work; Nguyen Thi
Thu Trang, Dang Nhu Ngoc, Nguyen Phu Thuong Nhan, Tran Thanh Truc, and Nguyen Quang Vinh wrote the original draft of the manuscript; Nguyen Thi Thu Trang and Pham Nguyen Thuy Dung reviewed and edited the manuscript.

\section{Acknowledgments}

This research was funded by Nguyen Tat Thanh University, Ho Chi Minh City, Vietnam.

\section{References}

[1] W. Dhifi, S. Bellili, S. Jazi, N. Bahloul, and W. Mnif, "Essential oils' chemical characterization and investigation of some biological activities: a critical review," Medicines, vol. 3, no. 4 , p. 25, 2016.

[2] C. Maes, S. Bouquillon, and M. L. Fauconnier, "Encapsulation of essential oils for the development of biosourced pesticides with controlled release: a review," Molecules, vol. 24, no. 14, Article ID 2539, 2019.

[3] N. Lammari, O. Louaer, A. H. Meniai, and A. Elaissari, "Encapsulation of essential oils via nanoprecipitation process: overview, progress, challenges and prospects," Pharmaceutics, vol. 12, no. 5, p. 431, 2020.

[4] U. K. Sharma, A. K. Sharma, and A. K. Pandey, "Medicinal attributes of major phenylpropanoids present in cinnamon," BMC Complementary and Alternative Medicine, vol. 16, no. 1, p. 156, 2016.

[5] E. R. Adlard, "Handbook of essential oils. Science, technology and applications," Chromatographia, vol. 72, no. 910, p. 1021, 2010.

[6] S. R. Macwan, B. K. Dabhi, K. D. Aparnathi, and J. B. Prajapati, "Essential oils of herbs and spices: their antimicrobial activity and application in preservation of food," International Journal of Current Microbiology and Applied Sciences, vol. 5, no. 5, pp. 885-901, 2016.

[7] K. H. C. Baser and G. Buchbauer, Handbook of Essential Oils: Science, Technology and Applications, CRC Press, Boca Raton, FL, USA, 2010.

[8] S. Bhavaniramya, S. Vishnupriya, M. S. Al-Aboody, R. Vijayakumar, and D. Baskaran, "Role of essential oils in food safety: antimicrobial and antioxidant applications," Grain \& Oil Science and Technology, vol. 2, no. 2, pp. 49-55, 2019.

[9] A. E. Edris, "Pharmaceutical and therapeutic Potentials of essential oils and their individual volatile constituents: a review," Phytotherapy Research, vol. 21, no. 4, pp. 308-323, 2007.

[10] M.-L. Tsai, C.-D. Lin, K. Khoo et al., "Composition and bioactivity of essential oil from citrus grandis (L.) osbeck 'mato peiyu' leaf,' Molecules, vol. 22, no. 12, p. 2154, 2017.

[11] B. Adorjan and G. Buchbauer, "Biological properties of essential oils: an updated review," Flavour and Fragrance Journal, vol. 25, no. 6, pp. 407-426, 2010.

[12] S. Burt, "Essential oils: their antibacterial properties and potential applications in foods-a review," International Journal of Food Microbiology, vol. 94, no. 3, pp. 223-253, 2004.

[13] W. He, X. Li, Y. Peng, X. He, and S. Pan, "Anti-oxidant and anti-melanogenic properties of essential oil from peel of pomelo cv. Guan xi," Molecules, vol. 24, no. 2, p. 242, 2019. 
[14] N. T. Lan-Phi and T. T. Vy, "Chemical composition, antioxidant and antibacterial activities of peels' essential oils of different pomelo varieties in the south of Vietnam," International Food Research Journal, vol. 22, no. 6, pp. 2426-2431, 2015.

[15] P. Van Hung, P. T. L. Chi, and N. T. L. Phi, "Comparison of antifungal activities of Vietnamese citrus essential oils," Natural Product Research, vol. 27, no. 4-5, pp. 506-508, 2013.

[16] R. S. Lemes, C. C. F. Alves, E. B. B. Estevam et al., "Chemical composition and antibacterial activity of essential oils from Citrus aurantifolia leaves and fruit peel against oral pathogenic bacteria," Anais da Academia Brasileira de Ciências, vol. 90, no. 2, pp. 1285-1292, 2018.

[17] O. B. Ajayi-Moses, C. O. Ogidi, and B. J. Akinyele, "Bioactivity of Citrus essential oils (CEOs) against microorganisms associated with spoilage of some fruits," Chemical and Biological Technologies in Agriculture, vol. 6, no. 1, p. 22, 2019.

[18] N. Maruyama, Y. Sekimoto, H. Ishibashi et al., "Suppression of neutrophil accumulation in mice by cutaneous application of geranium essential oil," Journal of Inflammation, vol. 2, no. 1, p. 1, 2005.

[19] A. São Pedro, I. Santo, C. Silva, C. Detoni, and E. Albuquerque, "The use of nanotechnology as an approach for essential oil-based formulations with antimicrobial activity," in Microbial Pathogens and Strategies for Combating Them, A. Méndez-Vilas, Ed., pp. 1364-1374, Formatex Publisher, Badajoz, Spain, 2013.

[20] S. van Vuuren and A. Viljoen, "Plant-based antimicrobial studies - methods and approaches to study the interaction between natural products," Planta Medica, vol. 77, no. 11, pp. 1168-1182, 2011.

[21] G. Cottarel and J. Wierzbowski, "Combination drugs, an emerging option for antibacterial therapy," Trends in Biotechnology, vol. 25, no. 12, pp. 547-555, 2007.

[22] S. Hemaiswarya, A. K. Kruthiventi, and M. Doble, "Synergism between natural products and antibiotics against infectious diseases," Phytomedicine, vol. 15, no. 8, pp. 639-652, 2008.

[23] A. Tanhaeian, M. H. Sekhavati, and M. Moghaddam, “Antimicrobial activity of some plant essential oils and an antimicrobial-peptide against some clinically isolated pathogens," Chemical and Biological Technologies in Agriculture, vol. 7, no. 1, p. 13, 2020.

[24] H. Wagner and G. Ulrich-Merzenich, "Synergy research: approaching a new generation of phytopharmaceuticals," Phytomedicine, vol. 16, no. 2-3, pp. 97-110, 2009.

[25] A. Mihai Grumezescu, "Essential oils and nanotechnology for combating microbial biofilms," Current Organic Chemistry, vol. 17, no. 2, pp. 90-96, 2013.

[26] M. Rai and A. Ingle, "Role of nanotechnology in agriculture with special reference to management of insect pests," Applied Microbiology and Biotechnology, vol. 94, no. 2, pp. 287-293, 2012.

[27] E. Worrall, A. Hamid, K. Mody, N. Mitter, and H. Pappu, "Nanotechnology for plant disease management," Agronomy, vol. 8, no. 12, p. 285, 2018.

[28] J. S. da Costa, A. S. Barroso, R. H. V. Mourão, J. K. R. da Silva, J. G. S. Maia, and P. L. B. Figueiredo, "Seasonal and antioxidant evaluation of essential oil from eugenia uniflora $L$., curzerene-rich, thermally produced in situ," Biomolecules, vol. 10 , no. 2 , p. $328,2020$.

[29] A. Detsi, E. Kavetsou, I. Kostopoulou et al., "Nanosystems for the encapsulation of natural products: the case of chitosan biopolymer as a matrix," Pharmaceutics, vol. 12, no. 7, p. 669, 2020.

[30] M. Kulak, F. Gul, and N. Sekeroglu, "Changes in growth parameter and essential oil composition of sage (Salvia officinalis L.) leaves in response to various salt stresses," Industrial Crops and Products, vol. 145, Article ID 112078, 2020.

[31] A. Maqsoudlou, E. Assadpour, H. Mohebodini, and S. M. Jafari, "Improving the efficiency of natural antioxidant compounds via different nanocarriers," Advances in Colloid and Interface Science, vol. 278, Article ID 102122, 2020.

[32] S. M. Jafari, E. Assadpoor, Y. He, and B. Bhandari, "Encapsulation efficiency of food flavours and oils during spray drying," Drying Technology, vol. 26, no. 7, pp. 816-835, 2008a.

[33] A. M. Burhan, S. M. Abdel-Hamid, M. E. Soliman, and O. A. Sammour, "Optimisation of the microencapsulation of lavender oil by spray drying," Journal of Microencapsulation, vol. 36, no. 3, pp. 250-266, 2019.

[34] N. P. Thuong Nhan, V. Tan Thanh, M. Huynh Cang et al., "Microencapsulation of lemongrass (cymbopogon citratus) essential oil via spray drying: effects of feed emulsion parameters," Processes, vol. 8, no. 1, p. 40, 2020.

[35] O. Tomazelli Júnior, F. Kuhn, P. J. M. Padilha et al., "Microencapsulation of essential thyme oil by spray drying and its antimicrobial evaluation against Vibrio alginolyticus and Vibrio parahaemolyticus," Brazilian Journal of Biology, vol. 78, no. 2, pp. 311-317, 2017.

[36] R. D. S. D. Veiga, R. Aparecida Da Silva-Buzanello, M. P. Corso, and C. Canan, "Essential oils microencapsulated obtained by spray drying: a review," Journal of Essential Oil Research, vol. 31, no. 6, pp. 457-473, 2019.

[37] A. S. Mujumdar, "Book review: handbook of industrial drying, third edition," Drying Technology, vol. 25, no. 6, pp. 1133-1134, 2007.

[38] A. Tanhaei, M. Mohammadi, H. Hamishehkar, and M. R. Hamblin, "Electrospraying as a novel method of particle engineering for drug delivery vehicles," Journal of Controlled Release, vol. 330, pp. 851-865, 2021.

[39] S. Tiwari, B. K. Singh, and N. K. Dubey, "Encapsulation of essential oils - a booster to enhance their bio-efficacy as botanical preservatives," Journal of Scientific Research, vol. 64 , no. 1, pp. 175-178, 2020.

[40] R. Busquets, "Emerging nanotechnologies in food science," Micro and Nano Technologies, Elsevier, Amsterdam, Netherlands, 2017.

[41] G. Q. Huang, J. X. Xiao, S. Q. Wang, and H. W. Qiu, "Rheological properties of O-carboxymethyl chitosan - gum Arabic coacervates as a function of coacervation $\mathrm{pH}$," Food Hydrocolloids, vol. 43, pp. 436-441, 2015.

[42] A. M. Bakry, S. Abbas, B. Ali et al., "Microencapsulation of oils: a comprehensive review of benefits, techniques, and applications," Comprehensive Reviews in Food Science and Food Safety, vol. 15, no. 1, pp. 143-182, 2016.

[43] A. Poshadri and A. Kuna, "Microencapsulation technology," Journal of Research ANGRAU, vol. 38, no. 1, pp. 86-102, 2010.

[44] S. J. Risch, "Encapsulation: overview of uses and techniques," in Encapsulation and Controlled Release of Food Ingredients, S. J. Risch and G. A. Reineccius, Eds., American Chemical Society, Washington, DC, pp. 2-7, 1995.

[45] E. Assadpour and S. M. Jafari, "Advances in spray-drying encapsulation of food bioactive ingredients: from 
microcapsules to nanocapsules," Annual Review of Food Science and Technology, vol. 10, no. 1, pp. 103-131, 2019.

[46] M. Alikhani, "Enhancing safety and shelf life of fresh-cut mango by application of edible coatings and microencapsulation technique," Food Science \& Nutrition, vol. 2, no. 3, pp. 210-217, 2014.

[47] S. C. Samantha, A. S. M. Bruna, R. M. Adriana, B. Fabio, A. R. Sandro, and R. C. A. Aline, "Drying by spray drying in the food industry: micro-encapsulation, process parameters and main carriers used," African Journal of Food Science, vol. 9, no. 9, pp. 462-470, 2015.

[48] J. Mujica-Álvarez, O. Gil-Castell, P. A. Barra et al., "Encapsulation of vitamins $\mathrm{A}$ and $\mathrm{E}$ as spray-dried additives for the feed industry," Molecules, vol. 25, no. 6, p. 1357, 2020.

[49] M. Szekalska, K. Sosnowska, A. Czajkowska-Kośnik, and K. Winnicka, "Calcium chloride modified alginate microparticles formulated by the spray drying process: a strategy to prolong the release of freely soluble drugs," Materials, vol. 11, no. 9, p. 1522, 2018.

[50] K. Kandansamy and P. D. Somasundaram, "Microencapsulation of colors by spray drying - a review," International Journal of Food Engineering, vol. 8, no. 2, 2012.

[51] C. Chang and M. T. Nickerson, "Encapsulation of omega 36-9 fatty acids-rich oils using protein-based emulsions with spray drying," Journal of Food Science and Technology, vol. 55, no. 8, pp. 2850-2861, 2018.

[52] D. S. Aniesrani Delfiya, K. Thangavel, N. Natarajan, R. Kasthuri, and R. Kailappan, "Microencapsulation of turmeric oleoresin by spray drying and in vitro release studies of microcapsules," Journal of Food Process Engineering, vol. 38, no. 1, pp. 37-48, 2015.

[53] M. Aghbashlo, H. Mobli, A. Madadlou, and S. Rafiee, "Fish oil microencapsulation as influenced by spray dryer operational variables," International Journal of Food Science \& Technology, vol. 48, no. 8, pp. 1707-1713, 2013a.

[54] T. Andrea, F. Marcela, C. Lucía, F. Esther, M. Elena, and M. Simona, "Microencapsulation of lipase and savinase enzymes by spray drying using Arabic gum as wall material," Journal of Encapsulation and Adsorption Sciences, vol. 6, no. 4, pp. 161-173, 2016.

[55] D. A. Botrel, S. V. Borges, M. I. Yoshida et al., "Properties of spray-dried fish oil with different carbohydrates as carriers," Journal of Food Science and Technology, vol. 54, no. 13, pp. 4181-4188, 2017.

[56] Y. Pang, X. Duan, G. Ren, and W. Liu, "Comparative study on different drying methods of fish oil microcapsules," Journal of Food Quality, vol. 2017, Article ID 1612708, 7 pages, 2017.

[57] J. P. Hecht and C. J. King, "Spray drying: influence of developing drop morphology on drying rates and retention of volatile substances. 1. Single-drop experiments," Industrial \& Engineering Chemistry Research, vol. 39, no. 6, pp. 17561765, 2000.

[58] J. P. Hecht and C. J. King, "Spray drying: influence of developing drop morphology on drying rates and retention of volatile substances. 2. Modeling," Industrial \& Engineering Chemistry Research, vol. 39, no. 6, pp. 1766-1774, 2000.

[59] C. M. Asensio, A. J. Paredes, M. P. Martin, D. A. Allemandi, V. Nepote, and N. R. Grosso, "Antioxidant stability study of oregano essential oil microcapsules prepared by spray-drying," Journal of Food Science, vol. 82, no. 12, pp. 2864-2872, 2017.

[60] S. Cortés-Camargo, J. Cruz-Olivares, B. E. Barragán-Huerta, O. Dublán-García, A. Román-Guerrero, and C. Pérez-
Alonso, "Microencapsulation by spray drying of lemon essential oil: evaluation of mixtures of mesquite gum-nopal mucilage as new wall materials," Journal of Microencapsulation, vol. 34, no. 4, pp. 395-407, 2017.

[61] M. Sotelo-Bautista, L. A. Bello-Perez, R. A. Gonzalez-Soto, J. Yañez-Fernandez, and J. Alvarez-Ramirez, "OSA-maltodextrin as wall material for encapsulation of essential avocado oil by spray drying," Journal of Dispersion Science and Technology, vol. 41, no. 2, pp. 235-242, 2020.

[62] S. Kausadikar, A. D. Gadhave, and J. Waghmare, "Microencapsulation of lemon oil by spray-drying and its application in flavour tea," Advances in Applied Science Research, vol. 6, no. 4, pp. 69-78, 2015.

[63] Z. Aksoylu and P. Günç Ergönül, "A review on encapsulation of oils," Celal Bayar Üniversitesi Fen Bilimleri Dergisi, vol. 13, no. 2, pp. 293-309, 2017.

[64] E. K. Bae and S. J. Lee, "Microencapsulation of avocado oil by spray drying using whey protein and maltodextrin," Journal of Microencapsulation, vol. 25, no. 8, pp. 549-560, 2008.

[65] F. Niu, D. Niu, H. Zhang et al., "Ovalbumin/gum Arabicstabilized emulsion: rheology, emulsion characteristics, and Raman spectroscopic study," Food Hydrocolloids, vol. 52, pp. 607-614, 2016.

[66] L. Xie, O. Ciftci, O. Ciftci, and Y. Zhang, "Encapsulation of astaxanthin-enriched camelina oil extract in ovalbumin/gum arabic stabilized emulsion with/without crosslinking by tannic acid," ES Food \& Agroforestry, vol. 1, pp. 77-84, 2020.

[67] H. Rajabi, M. Ghorbani, S. M. Jafari, A. Sadeghi Mahoonak, and G. Rajabzadeh, "Retention of saffron bioactive components by spray drying encapsulation using maltodextrin, gum Arabic and gelatin as wall materials," Food Hydrocolloids, vol. 51, pp. 327-337, 2015.

[68] K. Bigetti Guergoletto, K. Landucci Bonifácio, D. Sabbatini Barbosa et al., "Influence of spray-drying and room temperature storage on the anti- and prooxidant properties of fermented juçara pulp," Food Technology and Biotechnology, vol. 58, no. 1, pp. 29-37, 2020.

[69] I. A. Flores-Belmont, E. Palou, A. López-Malo, and M. T. Jiménez-Munguía, "Simple and double microencapsulation of Lactobacillus acidophilus with chitosan using spray drying," International Journal of Food Studies, vol. 4, no. 2, 2015.

[70] P. H. C. Felix, V. S. Birchal, D. A. Botrel, G. R. Marques, and S. V. Borges, "Physicochemical and thermal stability of microcapsules of cinnamon essential oil by spray drying," Journal of Food Processing and Preservation, vol. 41, no. 3, 2017.

[71] A. Gharsallaoui, G. Roudaut, O. Chambin, A. Voilley, and R. Saurel, "Applications of spray-drying in microencapsulation of food ingredients: an overview," Food Research International, vol. 40, no. 9, pp. 1107-1121, 2007.

[72] M. Bringas-Lantigua, I. Expósito-Molina, G. A. Reineccius, O. López-Hernández, and J. A. Pino, "Influence of spraydryer air temperatures on encapsulated Mandarin oil," Drying Technology, vol. 29, no. 5, pp. 520-526, 2011.

[73] S. M. Jafari, E. Assadpoor, Y. He, and B. Bhandari, "Recoalescence of emulsion droplets during high-energy emulsification," Food Hydrocolloids, vol. 22, no. 7, pp. 1191-1202, 2008b.

[74] I. Goubet, J.-L. Le Quere, and A. J. Voilley, "Retention of aroma compounds by carbohydrates: influence of their physicochemical characteristics and of their physical state a review," Journal of Agricultural and Food Chemistry, vol. 46, no. 5, pp. 1981-1990, 1998. 
[75] J. R. Kim and S. Sharma, "Acaricidal activities of clove bud oil and red thyme oil using microencapsulation against HDMs," Journal of Microencapsulation, vol. 28, no. 1, pp. 82-91, 2011.

[76] E. C. Frascareli, V. M. Silva, R. V. Tonon, and M. D. Hubinger, "Effect of process conditions on the microencapsulation of coffee oil by spray drying," Food and Bioproducts Processing, vol. 90, no. 3, pp. 413-424, 2012.

[77] M. Aghbashlo, H. Mobli, A. Madadlou, and S. Rafiee, "Influence of wall material and inlet drying air temperature on the microencapsulation of fish oil by spray drying," Food and Bioprocess Technology, vol. 6, no. 6, pp. 1561-1569, 2013 b.

[78] M. Bringas-Lantigua, D. Valdés, and J. A. Pino, "Influence of spray-dryer air temperatures on encapsulated lime essential oil," International Journal of Food Science \& Technology, vol. 47, no. 7, pp. 1511-1517, 2012.

[79] R. V. d. B. Fernandes, S. V. Borges, and D. A. Botrel, "Influence of spray drying operating conditions on microencapsulated rosemary essential oil properties," Ciência e Tecnologia de Alimentos, vol. 33, pp. 171-178, 2013.

[80] M. Y. Maskat, C. K. Lung, E. Momeny et al., "Temperature and feed rate effects properties of spray dried Hibiscus sabdariffa powder," International Journal of Drug Development and Research, vol. 6, no. 4, pp. 28-34, 2014.

[81] A. Madene, M. Jacquot, J. Scher, and S. Desobry, "Flavour encapsulation and controlled release - a review," International Journal of Food Science and Technology, vol. 41, no. 1, pp. 1-21, 2006.

[82] M. Radünz, H. C. dos Santos Hackbart, T. M. Camargo et al., "Antimicrobial potential of spray drying encapsulated thyme (Thymus vulgaris) essential oil on the conservation of hamburger-like meat products," International Journal of Food Microbiology, vol. 330, Article ID 108696, 2020.

[83] J. Jovanović, S. Krnjajić, J. Ćirković et al., "Effect of encapsulated lemongrass (Cymbopogon citratus L.) essential oil against potato tuber moth Phthorimaea operculella," Crop Protection, vol. 132, Article ID 105109, 2020.

[84] D. H. Kringel, W. M. F. Silva, B. Biduski et al., "Free and encapsulated orange essential oil into a $\beta$-cyclodextrin inclusion complex and zein to delay fungal spoilage in cakes," Journal of Food Processing and Preservation, vol. 44, no. 5, 2020.

[85] V. García-Díaz, V. Patiño, T. Vázquez, and K. Gil-Serna, “A novel niosome-encapsulated essential oil formulation to prevent Aspergillus flavus growth and aflatoxin contamination of maize grains during storage," Toxins, vol. 11, no. 11, p. $646,2019$.

[86] C. M. Bedoya-Serna, G. C. Dacanal, A. M. Fernandes, and S. C. Pinho, "Antifungal activity of nanoemulsions encapsulating oregano (Origanum vulgare) essential oil: in vitro study and application in Minas Padrão cheese," Brazilian Journal of Microbiology, vol. 49, no. 4, pp. 929-935, 2018.

[87] M. Hadian, A. Rajaei, A. Mohsenifar, and M. Tabatabaei, "Encapsulation of Rosmarinus officinalis essential oils in chitosan-benzoic acid nanogel with enhanced antibacterial activity in beef cutlet against Salmonella typhimurium during refrigerated storage," LWT, vol. 84, pp. 394-401, 2017.

[88] B. Niu, Z. Yan, P. Shao, J. Kang, and H. Chen, "Encapsulation of cinnamon essential oil for active food packaging film with synergistic antimicrobial activity," Nanomaterials, vol. 8, no. 8, p. 598, 2018.

[89] N. Riquelme, M. L. Herrera, and S. Matiacevich, "Active films based on alginate containing lemongrass essential oil encapsulated: effect of process and storage conditions," Food and Bioproducts Processing, vol. 104, pp. 94-103, 2017.
[90] J. Choi, L. Wang, E. Ammeter et al., "Evaluation of lipid matrix microencapsulation for intestinal delivery of thymol in weaned pigs," Translational Animal Science, vol. 4, no. 1, pp. 411-422, 2020.

[91] O. A. Attallah, A. Shetta, F. Elshishiny, and W. Mamdouh, "Essential oil loaded pectin/chitosan nanoparticles preparation and optimization via Box-Behnken design against MCF-7 breast cancer cell lines," RSC Advances, vol. 10, no. 15, pp. 8703-8708, 2020.

[92] L. Julianti Wijayadi and T. Rusliati Rusli, "Encapsulated lime peel essential oil (citrus hystrix) into chitosan nanoparticle: new entity to enhanced effectivity against propionilbacterium acne in vitro," IOP Conference Series: Materials Science and Engineering, vol. 852, Article ID 012016, 2020.

[93] K. Khezri, M. R. Farahpour, and S. Mounesi Rad, "Accelerated infected wound healing by topical application of encapsulated Rosemary essential oil into nanostructured lipid carriers," Artificial Cells, Nanomedicine, and Biotechnology, vol. 47, no. 1, pp. 980-988, 2019.

[94] S. A. Syed Ansar Ali, A. K. Amit Kumar Nayak, K. K. Kalyan Kumar Sen, and T. Prabhakar T, "Preparation and characterization of vetiver oil encapsulated polymeric microcapsules for sedative and hypnotic activity," International Journal of Research in Pharmaceutical Sciences, vol. 10, no. 4, pp. 3616-3625, 2019.

[95] M. Ghodrati, M. R. Farahpour, and H. Hamishehkar, "Encapsulation of Peppermint essential oil in nanostructured lipid carriers: in-vitro antibacterial activity and accelerative effect on infected wound healing," Colloids and Surfaces A: Physicochemical and Engineering Aspects, vol. 564, pp. 161169, 2019.

[96] G. Wadhwa, S. Kumar, V. Mittal et al., "Encapsulation of babchi essential oil into microsponges: physicochemical properties, cytotoxic evaluation and anti-microbial activity," Journal of Food and Drug Analysis, vol. 27, no. 1, pp. 60-70, 2019.

[97] R. S. Borges, H. Keita, B. L. S. Ortiz et al., “Anti-inflammatory activity of nanoemulsions of essential oil from Rosmarinus officinalis L.: in vitro and in zebrafish studies," Inflammopharmacology, vol. 26, no. 4, pp. 1057-1080, 2018.

[98] A. Pujiastuti, E. Cahyono, and W. Sumarni, "Encapsulation of citronellal from citronella oil using $\beta$-cyclodextrin and its application as mosquito (Aedes aegypti) repellent," Journal of Physics: Conference Series, vol. 824, Article ID 012016, 2017.

[99] B. Jamil, R. Abbasi, S. Abbasi et al., "Encapsulation of cardamom essential oil in chitosan nano-composites: in-vitro efficacy on antibiotic-resistant bacterial pathogens and cytotoxicity studies," Frontiers in Microbiology, vol. 7, 2016.

[100] G. C. Türkoğlu, A. M. Sarışık, G. Erkan, M. S. Yıkılmaz, and O. Kontart, "Micro- and nano-encapsulation of limonene and permethrin for mosquito repellent finishing of cotton textiles," Iranian Polymer Journal, vol. 29, no. 4, pp. 321-329, 2020.

[101] B. S. Beşen, "Production of disposable antibacterial textiles via application of tea tree oil encapsulated into different wall materials," Fibers and Polymers, vol. 20, no. 12, pp. 2587-2593, 2019.

[102] S. Karagonlu, G. Başal, F. ÖzyIldIz, and A. Uzel, "Preparation of thyme oil loaded microcapsules for textile applications," International Journal of New Technology and Research, vol. 4, no. 3, Article ID 263122, 2018.

[103] A. Sharkawy, I. P. Fernandes, M. F. Barreiro, A. E. Rodrigues, and T. Shoeib, "Aroma-loaded microcapsules with antibacterial activity for eco-friendly textile application: 
synthesis, characterization, release, and green grafting," Industrial \& Engineering Chemistry Research, vol. 56, no. 19, pp. 5516-5526, 2017.

[104] P. Vinayagamoorthy, B. Senthilkumar, K. Patchiyappan, and R. Kavitha, "Microencapsulated lemongrass oil for mosquito repellent finishing OF knitted cotton wear," Asian Journal of Pharmaceutical and Clinical Research, vol. 10, no. 6, p. 303, 2017.

[105] F. M. Bezerra, O. G. Carmona, C. G. Carmona, M. J. Lis, and F. F. de Moraes, "Controlled release of microencapsulated citronella essential oil on cotton and polyester matrices," Cellulose, vol. 23, no. 2, pp. 1459-1470, 2016.

[106] R. Geethadevi and V. Maheshwari, "Long-lasting UV protection and mosquito repellent finish on bamboo/tencel blended fabric with microencapsulated essential oil," Indian Journal of Fibre and Textile Research, vol. 40, no. 2, pp. 175-179, 2015.

[107] C. Liu, B. Liang, G. Shi et al., "Preparation and characteristics of nanocapsules containing essential oil for textile application," Flavour and Fragrance Journal, vol. 30, no. 4, pp. 295-301, 2015.

[108] S. Ghayempour and S. M. Mortazavi, "Microwave curing for applying polymeric nanocapsules containing essential oils on cotton fabric to produce antimicrobial and fragrant textiles," Cellulose, vol. 22, no. 6, pp. 4065-4075, 2015.

[109] J. Gustavsson, C. Cederberg, and U. Sonesson, "Global food losses and food waste: extent, causes and prevention; study conducted for the international congress save," 2011, http:// www.fao.org/save-food/resources/keyfindings/en/.

[110] M. Leyva Salas, J. Mounier, F. Valence, M. Coton, A. Thierry, and E. Coton, "Antifungal microbial agents for food biopreservation-A review," Microorganisms, vol. 5, no. 3, p. 37, 2017.

[111] A. B. Snyder and R. W. Worobo, "Fungal spoilage in food processing," Journal of Food Protection, vol. 81, no. 6, pp. 1035-1040, 2018.

[112] D. L. Archer, "Preservation microbiology and safety: evidence that stress enhances virulence and triggers adaptive mutations," Trends in Food Science \& Technology, vol. 7, no. 3, pp. 91-95, 1996.

[113] G. D. Mogoşanu, A. M. Grumezescu, C. Bejenaru, and L. E. Bejenaru, "Natural products used for food preservation," in Food Preservation, pp. 365-411, Elsevier, 2017.

[114] M. Boskovic, M. Glisic, J. Djordjevic, J. Vranesevic, V. Djordjevic, and M. Z. Baltic, "Preservation of meat and meat products using nanoencapsulated thyme and oregano essential oils," IOP Conference Series: Earth and Environmental Science, vol. 333, 2019.

[115] S. Li, J. Zhou, Y. Wang et al., "Physicochemical and antimicrobial properties of hydroxypropyl methylcellulosecinnamon essential oil emulsion: effects of micro- and nanodroplets," International Journal of Food Engineering, vol. 15, no. 9, 2019.

[116] M. Pabast, N. Shariatifar, S. Beikzadeh, and G. Jahed, "Effects of chitosan coatings incorporating with free or nano-encapsulated Satureja plant essential oil on quality characteristics of lamb meat," Food Control, vol. 91, pp. 185-192, 2018.

[117] R. Ribeiro-Santos, M. Andrade, and A. Sanches-Silva, "Application of encapsulated essential oils as antimicrobial agents in food packaging," Current Opinion in Food Science, vol. 14, pp. 78-84, 2017.

[118] D. Morais, R. Guedes, and M. Lopes, "Antimicrobial approaches for textiles: from research to market," Materials, vol. 9, no. 6, p. 498, 2016.
[119] L. J. Wijayadi and T. R. Rusli, "Encapsulated lime peel essential oil (Citrus hystrix) into chitosan nanoparticle: new entity to enhanced effectivity against propionilbacterium acne in vitro," IOP Conference Series: Materials Science and Engineering, vol. 852, no. 1, p. 012016, 2020.

[120] S. Khanna and J. N. Chakraborty, "Mosquito repellent activity of cotton functionalized with inclusion complexes of $\beta$-cyclodextrin citrate and essential oils," Fashion and Textiles, vol. 5, no. 1, p. 9, 2018.

[121] A. Agnihotri, S. Wazed Ali, A. Das, and R. Alagirusamy, "Insect-repellent textiles using green and sustainable approaches," in The Impact and Prospects of Green Chemistry for Textile Technology, pp. 307-325, Woodhead Publishing, Sawston, UK, 2019.

[122] M. Joshi, S. Ali, R. Purwar, and S. Rajendran, "Ecofriendly antimicrobial finishing of textiles using bioactive agents based on natural products," Indian Journal of Fiber \& Textile Research, vol. 34, no. 3, pp. 295-304, 2009.

[123] F. V. Leimann, O. H. Gonçalves, R. A. F. Machado, and A. Bolzan, "Antimicrobial activity of microencapsulated lemongrass essential oil and the effect of experimental parameters on microcapsules size and morphology," Materials Science and Engineering: C, vol. 29, no. 2, pp. 430-436, 2009.

[124] J. U. Rehman, A. Ali, and I. A. Khan, "Plant based products: use and development as repellents against mosquitoes: a review," Fitoterapia, vol. 95, pp. 65-74, 2014.

[125] M. S. Stan, L. Chirila, A. Popescu, D. M. Radulescu, D. E. Radulescu, and A. Dinischiotu, "Essential oil microcapsules immobilized on textiles and certain induced effects," Materials, vol. 12, no. 12, p. 2029, 2019.

[126] F. Özyildiz, S. Karagönlü, G. Basal, A. Uzel, and O. Bayraktar, "Micro-encapsulation of ozonated red pepper seed oil with antimicrobial activity and application to nonwoven fabric," Letters in Applied Microbiology, vol. 56, no. 3, pp. 168-179, 2013.

[127] M. Periolatto, F. Ferrero, C. Vineis, A. Varesano, and G. Gozzelino, "Novel antimicrobial agents and processes for textile applications," in Antibacterial AgentsInTech, London, UK, 2017. 